\title{
Realising a vision of no net loss through marine biodiversity offsetting in Australia
}

Holly J. Niner ${ }^{a^{*}}$, Ben Milligan ${ }^{b}$, Peter J.S. Jones ${ }^{c}$, Craig A. Styan $^{a}$

\author{
a University College London, Australia. Torrens Building, 220 Victoria Square, Adelaide 5000, Australia \\ ${ }^{b}$ Centre for Law and Environment, University College London, Bentham House, Endsleigh Gardens, \\ London WC1H OEG, United Kingdom \\ ${ }^{c}$ Department of Geography, University College London, Pearson Building, Gower Street, London WC1E \\ 6BT, United Kingdom
}

* Corresponding author: holly.niner.13@ucl.ac.uk

\begin{abstract}
Biodiversity offsets are increasingly used in policy frameworks to regulate the environmental impacts of development including projects located in marine environments. Scientific knowledge gaps and other practical challenges have necessitated flexibility concerning the manner in which key offsetting principles are implemented in policy frameworks relevant to such environments. The potential tradeoff of such flexibility is that consequent marine offsetting practice may not be compatible with the ultimate objective of no net loss of biodiversity. Here we present a systematic review of marine and coastal development projects in Australia, examining how offsetting is being implemented in practice. Forty-two (42) projects were assessed, predominantly located in Queensland and Western Australia and associated with the development and operation of ports. We find that application of key biodiversity offsetting principles (e.g. ecological equivalence) was frequently incomplete or absent. For approximately $50 \%$ of reviewed projects we were unable to identify public information concerning how offsetting requirements were established. The current environmental outcomes of marine biodiversity offsetting in Australia are unclear but there are indications that it is unlikely to achieve no net loss of biodiversity.
\end{abstract}

\section{Keywords}

Biodiversity offsetting, Compensation, Mitigation hierarchy, marine offsets, Environmental Impact Assessment

\section{Highlights}

- Systematic review of the marine application of biodiversity offsetting in Australia.

- Marine offsets were most commonly identified in Queensland and Western Australia.

- Key principles for successful biodiversity offsetting were often absent.

- Transparency in application of mitigation hierarchy and offset definition is absent.

This is the authors' version of the final accepted Ocean \& Coastal Management manuscript. Elsevier $\odot$ 2017. This manuscript version is made available under the CC-BY-NC-ND 4.0 license. DOI: 10.1016/j.ocecoaman.2017.07.006

\section{@creative}




\section{Introduction}

In response to the continuing decline of biodiversity attributable to human activities (UNEP, 2012), biodiversity offsetting has been increasingly used to manage environmental impacts from development (Bull et al., 2013; Madsen et al., 2010; Maron et al., 2015). Biodiversity offsetting aims to secure an objective of no net loss (NNL) of biodiversity by requiring that any predicted residual environmental impacts (biodiversity losses) of development are compensated in the form of ecologically equivalent biodiversity gains (BBOP, 2012; McKenney and Kiesecker, 2010; ten Kate et al., 2004). The concept builds on the principle of the mitigation hierarchy, which underpins environmental impact assessment (EIA) processes that are used globally in many planning and consenting frameworks. The mitigation hierarchy stipulates that impacts should first be avoided, mitigated and then, as a last resort, any residual effects compensated (BenDor, 2009; Corps and EPA, 1990; Madsen et al., 2010) (Fig. 1). In theory, biodiversity offsets through an aim of NNL reduce the flexibility in how compensation agreements are reached. Assessments of the feasibility of offsets should address the application of the mitigation hierarchy in a strict hierarchical process and stipulate that the steps of avoidance and mitigation are revisited where offsets present greater uncertainty of success (Bull et al., 2013; Gibbons and Lindenmayer, 2007; Maron et al., 2012; McKenney and Kiesecker, 2010; Moilanen et al., 2009) (Fig. 1b). For example, it is commonly accepted that NNL is best achieved through direct offsetting mechanisms that achieve measurable biodiversity gains such as like for like habitat restoration (Maron et al., 2012). Many biodiversity offsetting policies stipulate a clear preference that direct and like-for-like measures are first explored as options, in preference to the use of indirect and out of kind measures such as research and education programmes (Bos et al., 2014; Bull et al., 2013; Maron et al., 2012).

a.

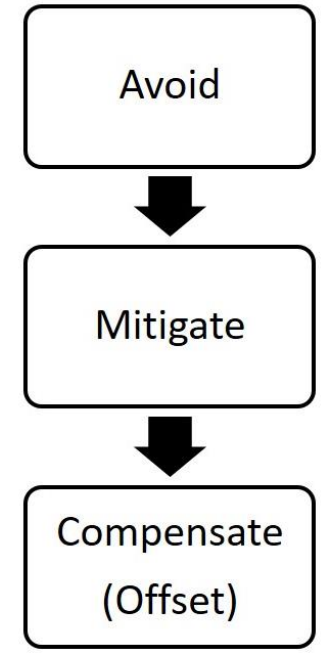

b.

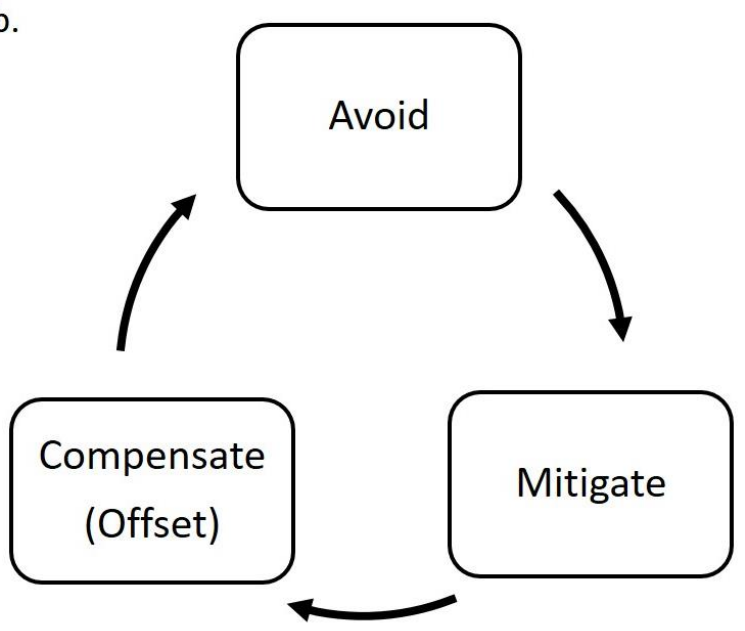

Figure 1. The mitigation hierarchy as (a) applied in a linear process and as (b) applied through an iterative process as promoted by the robust assessment of biodiversity offset feasibility. Offsets should only be applied as a last resort as a form of compensation. 
The key principles underpinning biodiversity offsetting and identified as essential to achieve NNL are the same for both terrestrial and marine environments. They can be distilled into three distinct themes relating to equivalence, compliance, and the application of the mitigation hierarchy (Crowder and Norse, 2008; Day and Dobbs, 2013; UNEP-WCMC, 2016). Whilst there are common challenges to the implementation of biodiversity offsets across terrestrial and marine environments, there are some difficulties unique to the marine environment (Bos et al., 2014; Crowder and Norse, 2008; Day and Dobbs, 2013; UNEP-WCMC, 2016). Impact quantification and attribution is difficult in marine contexts, given baseline data for such environments is often scarce and consequently ecological understanding of these systems and impact pathways is often poor. Furthermore, improving our current understanding to support better impact prediction is complicated and costly in marine environments, where ecological function is dependent on a range of highly variable physical, chemical and biological controls, operating on a massive range of temporal and spatial scales (Bos et al., 2014). As a possible result, impact quantification has been found to be absent or simplified in reviews of EIA documentation for marine projects (Soulé, 1985; Vaissière et al., 2014).

Offset success has also been shown to be contingent on the implementation of an effective compliance regime (Brown and Veneman, 2001; Kentula, 2000; Robertson and Hayden, 2008). In marine contexts, compliance is complicated not only by the diffuse nature of impact pathways and connectivity between ecological components but also often by the "horrendogram" of existing laws and policies governing environmental protection in many countries, and the absence of clearly defined property rights (Boyes and Elliott, 2014).

This paper presents a review of current biodiversity offsetting practice in the marine environment in Australia, based on an analysis of the Australian policy context and online planning documentation associated with major coastal development dating from the 1970s. By reviewing the development types, actions and impact pathways triggering biodiversity offsetting requirements within consents, we assess current practice in relation to an aim of NNL.

\section{Legal and policy context in Australia}

Australia is one of six countries including Canada, Colombia, France, Germany and the US that currently have national biodiversity offsetting policies in place (Australian Government, 2012; Niner et al., 2017). Five of Australia's six states have also established biodiversity offsetting policies that are applicable to marine environments (Niner et al., 2017). Despite its relatively advanced policy basis supporting biodiversity offsetting, Australia has only recently started to develop policy specifically applicable to marine environments (Maron et al., 2016). 
Environmental impacts in Australia are managed across three levels of government - Commonwealth, State or Territory and, local. Impacts to matters of national environmental significance are managed under the Commonwealth Environment Protection and Biodiversity Conservation Act (EPBC Act). In the marine area these include a range of receptors including world heritage properties, listed threatened species and ecological communities, Commonwealth marine areas, and the Great Barrier Reef Marine Park (Department of the Environment and Energy, 1999). At a state level, there a range of matters for which impacts may trigger offsetting requirements, in particular those relating to fish habitat and native vegetation (Niner et al., 2017). Bilateral agreements are in place to avoid duplication of EIA processes at a Commonwealth and State/Territory level and within the Great Barrier Reef Marine Park (ANEDO, 2014; Australian Government, 2017). Other legislation and policies influence how tests of significance are applied and the options available for offsetting. For example, in some jurisdictions local policy classifying an area as being of 'urban use' allows for loss of some habitat such as seagrass which prevents the realisation of an aim of NNL in these areas (Kilminster et al., 2015). Furthermore, establishing marine offset projects is complicated by the overlapping use of an area by different sectors and activities such as shipping and both commercial and recreational fishing. The absence of clearly defined property rights and overlapping use of marine environments and resources prevents the easy isolation and protection of an area for habitat restoration.

At a national level, guidance within Australia's EPBC Act Environmental Offsets Policy is in line with accepted best practice for biodiversity offsets in most areas, and outlines the need for a robust and transparent application of the mitigation hierarchy (Australian Government, 2012; BBOP, 2012). However, the requirement for direct effort to form $90 \%$ of all offsetting measures is not applied in a marine context where uncertainty is acknowledged as being "so high that it isn't possible to determine a direct offset that is likely to benefit the protected matter" (Australian Government, 2012). The aims of the EPBC Act Environmental Offsets Policy are echoed in state-level policy, where the challenges of marine application (when explicitly considered) are addressed through flexibility in the implementation of indirect (and 'out of kind') offsetting measures (Fairfull, 2013; Queensland Government, 2016; WAMSI, 2014). For example, current practice in Queensland, New South Wales and Western Australia is to accommodate the challenges presented by the application of marine biodiversity offsets by pooling financial offsets for strategic conservation effort (Fairfull, 2013; Queensland Government, 2016; WAMSI, 2014). This flexibility allows the uncertainty of specific marine impact assessments to be managed particularly to assist where direct measures are challenging and there is inherent difficult in achieving biodiversity gains of a similar type to that lost (Miller et al., 2015). Australian policy does not support 'trading up' across ecological components to benefit biodiversity of greater conservation value as compared to that lost (Australian Government, 2012; Bull et al., 2015). This further complicates the use of indirect offsets through removing the option to invest in biodiversity of a higher perceived value. Here we investigate how the flexibility of relevant policy frameworks in Australia influences the application of biodiversity offsets in the marine environment, and what outcomes this presents for biodiversity. 


\section{Methods and sample selection}

\subsection{Data sources}

Information was sourced through a systematic review of planning applications available on Australian government planning websites for development projects that involved predicted residual marine environmental impacts. The review is limited to those projects listed on government planning portals, the availability of which varies between state both in terms temporal coverage, ranging from eight to over forty years of availability, and the type of information (electronic appendix 1). Source material includes environmental impact statements and associated evidence, government assessments of this information and recommendation reports and submissions from stakeholders relating to the EIA process. Where available, this material has been supplemented by further information sourced from project proponent websites.

\subsection{Sample selection}

Inclusion of projects in this review was based on the presence of biodiversity offsetting requirements within consenting documentation. For the purposes of this review marine biodiversity offsets were defined as ex-ante approaches to environmental compensation, where requirements for compensatory action have been stipulated in planning decisions in response to identified impacts to sub-tidal marine ecological receptors (including sub-tidal habitat and species dependent on sub-tidal habitat). As such, this review excludes impacts to inter-tidal habitats such as mangrove and saltmarsh. Post-consent agreements for rectifying unforeseen impacts or site-rehabilitation at the point of decommissioning were not included within this review.

A total of 43 projects were identified where marine biodiversity offsets were stipulated as part of their consent. One project comprised a strategic assessment for a proposed development plan where offsets were likely to be integral to any planning consent granted underneath the proposed strategy. However, but given the absence of specific offsetting requirements at this strategic stage, this project has not been included in the analysis. Seven of the remaining 42 projects, all located in Queensland, were not included in assessment of the offsetting mechanisms applied owing to insufficient available information for analysis (section 3.1.3. Definition of offsets). While those seven projects had associated offsetting requirements, specific definition of these were still pending at the point of decision owing to outstanding project design finalisation (electronic appendix 2). A further two projects were progressing through the consenting process at the point of review (in Queensland and South Australia), but were included in the analysis because clear commitments to offsets were identified in the documentation available. 


\subsection{Criteria for analysis}

Project documentation was analysed for information relating to impact identification, including the ecological receptors (species or habitat) affected and the actions that led to their degradation or loss (impact pathway e.g. dredging, port development). Impact pathways could be considered to be direct such as the removal of habitat by the installation of a structure or indirect such as a decrease in foraging or breeding habitat availability for a species as a result of recreational disturbance or use of an area. Further detail on biodiversity offsetting requirements was also recorded. This detail included the mechanism used to implement the offset (Bull et al., 2013; Madsen et al., 2010), and the decision process followed when agreeing the form of the offset (Table 2). The criteria used to analyse decision processes were based on the principles identified as essential for biodiversity offsetting success, specifically the application of the mitigation hierarchy, equivalence and compliance (BBOP, 2012; Bos et al., 2014). Explicit documentation of the process by which the mitigation hierarchy is followed is not often included in detail within planning documentation beyond detailing the use of best practice to minimise impacts. As such, information relating to the process of the definition of offset requirement was recorded. This information was recorded as the presence/absence of information against the following criteria: offset definition at the point of consent; assessments of offset equivalence (with impact); assessment of offset feasibility; and, associated compliance arrangements (Table 1).

Table 1. Definitions of marine biodiversity offset mechanisms.

\begin{tabular}{|c|c|}
\hline Offset mechanism & Definition \\
\hline Rehabilitation & Habitat or species populations are to be created or enhanced. \\
\hline Management & $\begin{array}{l}\text { Measures to improve biodiversity outcomes can include management of - } \\
\text { activities such as boating, shipping, fishing, and recreational use; feral predator } \\
\text { and weed control; or land-use change most commonly focusing on agricultural } \\
\text { practice. The implementation of a ranger programme through the employment } \\
\text { of individuals to undertake conservation activity is also considered a } \\
\text { management action. In this case management excludes efforts to directly create } \\
\text { or rehabilitate habitat. }\end{array}$ \\
\hline Protection & $\begin{array}{l}\text { Area of habitat or populations to be protected, through designation or other } \\
\text { means. }\end{array}$ \\
\hline Research & $\begin{array}{l}\text { Research programme to be developed and funded or contributions paid if } \\
\text { already in existence. Research is often linked to the ecological receptor at risk } \\
\text { and associated impact pathways with a view to improve future understanding } \\
\text { and management. }\end{array}$ \\
\hline Education & $\begin{array}{l}\text { Environmental education programme to be developed and funded or } \\
\text { contributions paid if already in existence. Often linked to ecological receptor at } \\
\text { risk or wider local ecosystem. }\end{array}$ \\
\hline In-lieu fee (ILF) & $\begin{array}{l}\text { Contributions to a wider fund that may or may not be in existence at the point } \\
\text { of consent, to deliver a specific aim such as research or management. }\end{array}$ \\
\hline Offset package & $\begin{array}{l}\text { A commitment to deliver a range of discrete offsetting projects through various } \\
\text { mechanisms. }\end{array}$ \\
\hline
\end{tabular}


Table 2. Terms and criteria used to analyse how marine biodiversity offset requirements were defined.

\begin{tabular}{ll}
\hline Process assessment criteria & Definition \\
\hline Impact quantification & $\begin{array}{l}\text { Impacts are explicitly identified and expressed in numerical terms either in } \\
\text { relation to the spatial extent of habitat or in terms of species numbers. This } \\
\text { quantification may or may not relate to the quality of habitat or the health of a } \\
\text { population and the significance of the impact on wider population viability. }\end{array}$ \\
\hline Offset definition & $\begin{array}{l}\text { Offsetting requirements are confirmed or detailed at the point of consent. } \\
\text { Definition includes consideration of the location of the offset and the timescale } \\
\text { and means by which it will be implemented. }\end{array}$ \\
\hline Assessment of equivalence & $\begin{array}{l}\text { Evidence of consideration of the relative values of the biodiversity losses or } \\
\text { impacts against the offset, relating to areas and quality of habitat for direct } \\
\text { offsets and biodiversity gains (or otherwise) for indirect offsets. E.g. application } \\
\text { of a metric to calculate losses and gains. }\end{array}$ \\
\hline Insurance & $\begin{array}{l}\text { Evidence of the application of measures of success of offsets, relating but not } \\
\text { limited to monitoring against indicators of success, adaptive management and } \\
\text { bonds against achieving aims of project. }\end{array}$ \\
\hline Compliance & $\begin{array}{l}\text { Evidence of consideration of the relative responsibilities for implementation or } \\
\text { success of an offset and enforcement procedures. }\end{array}$ \\
\hline
\end{tabular}

\section{Results}

\subsection{Spatial and temporal patterns in the use of marine offsets}

In line with trends in the number of EPBC referrals, the use of biodiversity offsets within marine development consenting has increased over the last decade (Fig. 2) with a peak between 2009 and 2013 (Harvey and Clarke, 2012). The earliest marine biodiversity offsetting requirement was issued in 1994 for an aggregate dredging project in Western Australia. While explicit use of the terms 'biodiversity offset' or 'NNL' was not made in that project's documentation, commitments to research on, and the rehabilitation of seagrass habitat in the area were clearly linked to the risk of loss of seagrass habitat. Furthermore, in subsequent extensions of this consent the offsetting project was expanded and then specifically referred to as an offset.

The greatest numbers of projects with associated marine biodiversity offsets were identified in Queensland (18) and Western Australia (14), with fewer in New South Wales (5), South Australia (3) and the Northern Territory (2). No projects with marine biodiversity offset requirements were found in Tasmania or Victoria. 


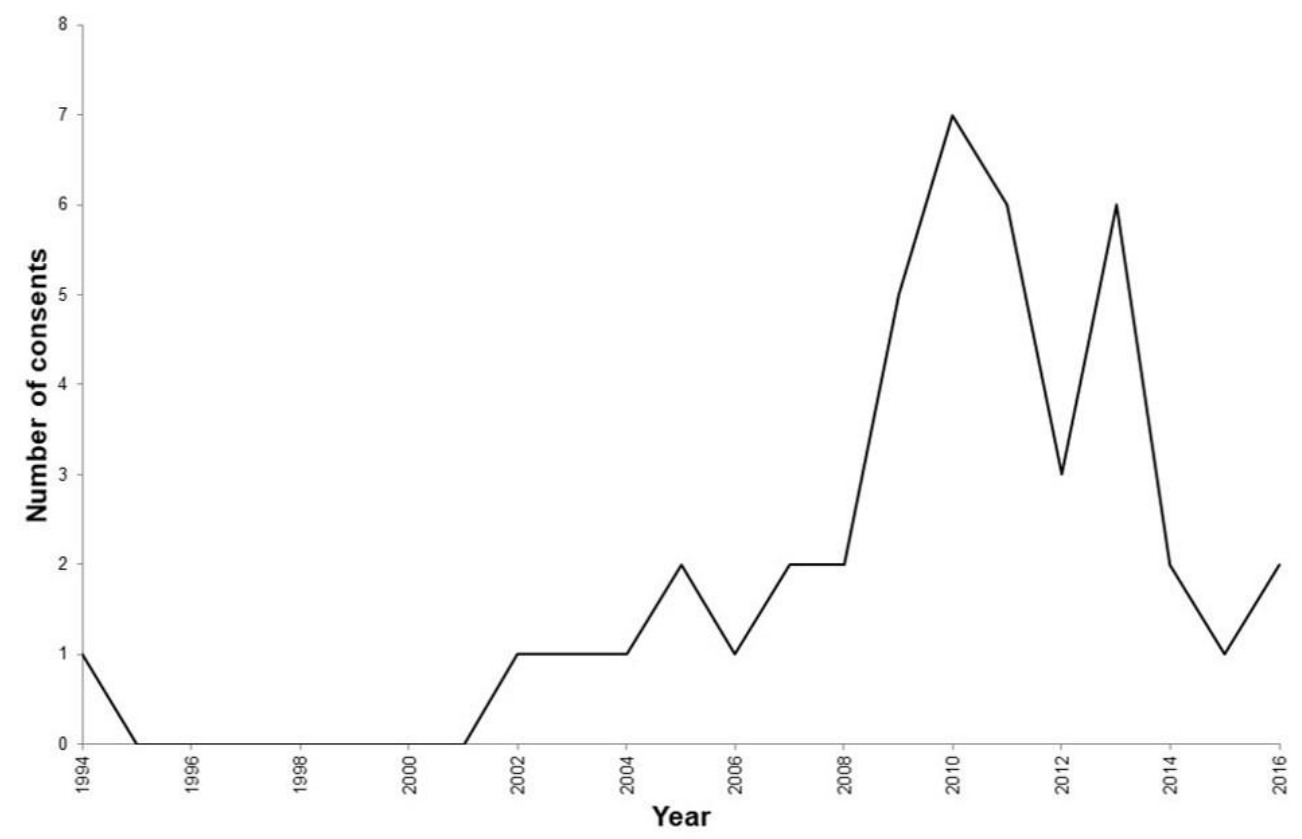

Figure 2. Number of major project consents stipulating marine biodiversity offsets by year $(n=42)$.

Over half of the 42 projects included within the review involved commercial port development and associated works, such as capital and maintenance dredging (Table 3). The majority of these port development projects were associated with liquefied natural gas (LNG) production and export facilities, along with ports for other resource commodity exports such as iron ore and coal. There was a single case relating to an increase in port capacity to support cruise shipping (in Queensland). Marina development for recreational vessels, ancillary commercial activity relating to fishing, often including a residential or entertainment precinct, was the second most common class of development to trigger marine offsetting requirements (eight projects). Aggregate dredging triggered four requirements for marine offsets within associated consents, although three of these related to the same project; each stage of expansion was assessed independently and effectively issued on three occasions and so, in this analysis, have been considered as three separate projects. Pipeline installation triggered two instances of marine offsets within associated consents. Increased pressures associated with shipping, cable laying, aquaculture, desalination plants and the development of a landing facility for terrestrial infrastructure also led to offsetting requirements for impacts to the marine environment (Table 3 ). 
Table 3. The type of development project that triggered the application of marine biodiversity offsets within development consents and the frequency of occurrence within the review sample $(n=42) .{ }^{*}$ includes smaller-scale commercial use such as fishing, ${ }^{* *}$ relates to development of a 'landing facility' as opposed to full port development activity.

\begin{tabular}{|c|c|c|c|c|c|c|}
\hline Type of development & NSW & NT & QLD & SA & WA & Total \\
\hline $\begin{array}{l}\text { Commercial port and } \\
\text { associated works }\end{array}$ & 1 & 2 & 10 & 1 & 9 & 23 \\
\hline $\begin{array}{l}\text { Marina and associated } \\
\text { works* }\end{array}$ & - & - & 5 & 1 & 2 & 8 \\
\hline Aggregates dredging & - & - & - & - & 3 & 3 \\
\hline Pipeline installation & - & - & 2 & - & - & 2 \\
\hline Aquaculture & 1 & - & - & - & - & 1 \\
\hline Cable laying & 1 & - & - & - & - & 1 \\
\hline Desalination plants & 1 & - & - & - & - & 1 \\
\hline Increased shipping & - & - & 1 & - & - & 1 \\
\hline Terrestrial infrastructure & 1 & - & - & - & - & 1 \\
\hline Other** & - & - & - & 1 & - & 1 \\
\hline
\end{tabular}

\subsection{Impact pathways as triggers for marine offsets}

The impact pathways triggering marine biodiversity offsetting requirements were almost equally distributed between direct and indirect impact pathways (Fig. 3). Over a quarter of all marine biodiversity offset triggers can be attributed to direct impacts to seagrass habitat (27\%). However, over ninety percent of direct marine biodiversity offset triggers (92\%) can be attributed to impacts to marine habitat with only $6 \%$ relating to impacts to marine species and $2 \%$ to undefined receptors (Fig. 3). 


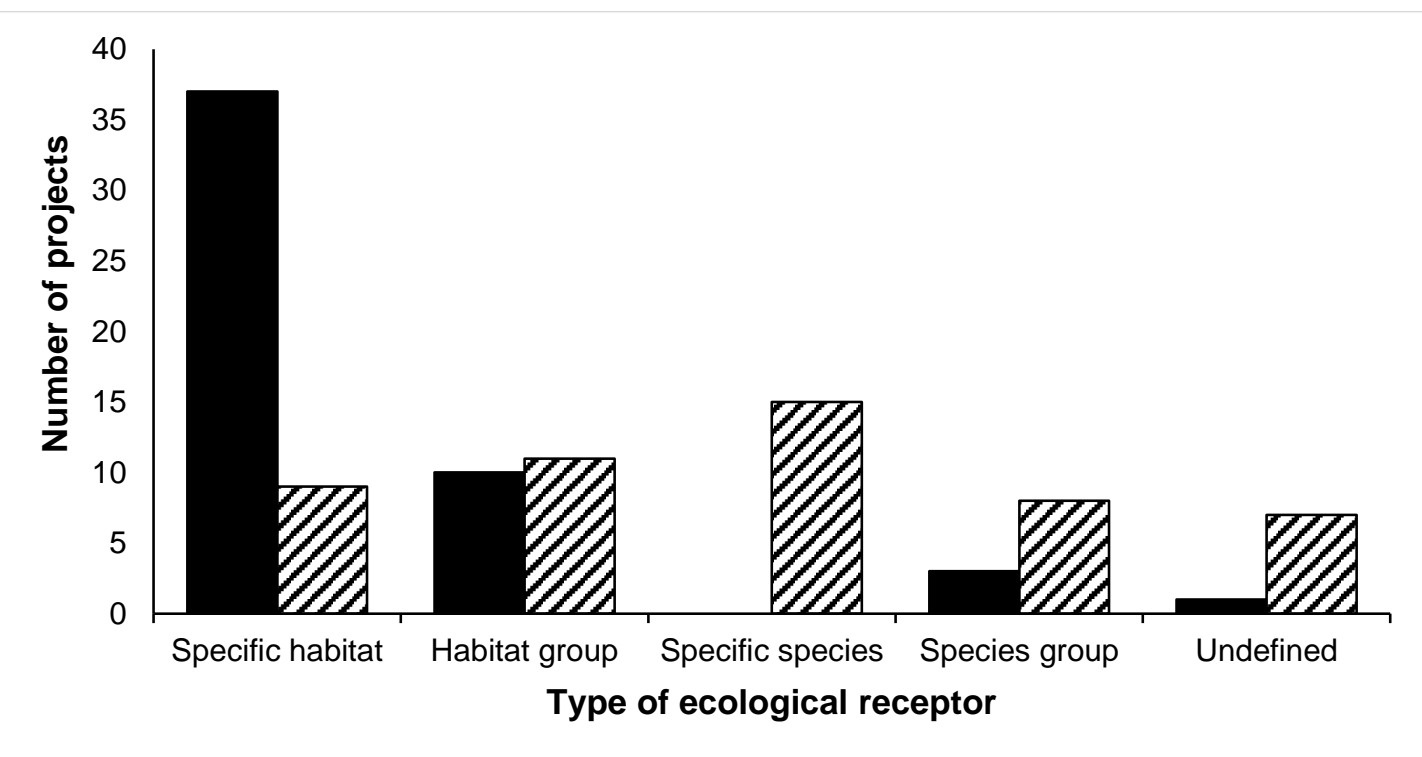

Figure 3. Impact pathways leading to marine biodiversity offset requirements in Australian development consent ( $n=42)$. The number of projects indicates the count of offset triggers by ecological receptor through direct (solid fill) and indirect (hatched) impact pathways. Direct impact pathways include dredging, dredge disposal, land reclamation, structure installation and trenching. Indirect pathways include increased shipping, recreational pressure, marine noise and light disturbance. Specific habitats include seagrass, algae and reef. Specific species include marine mammals, turtles, birds and fish. Habitat groups relate to descriptors including marine habitat and benthos. Species groups relate to the descriptor marine species. Undefined ecological receptor refers to absence of impact quantification and encompasses the descriptor 'sensitive area'. The number of projects is greater than the total sample size as many marine biodiversity offsets are triggered by impacts to multiple ecological receptors.

In contrast, nearly half of triggers relating to indirect impact pathways related to impacts to marine species $(46 \%)$, with $40 \%$ relating to marine habitats and $14 \%$ to undefined receptors (Fig. 3 ). The specific ecological receptors most commonly affected through indirect impact pathways, such as through disturbance by lighting or use of an area, were turtles (12\%) and marine mammals (12\%). Not all ecological receptors that triggered offsets were identified to a particular species or taxon, but were instead listed more broadly in groupings (16\%). Impacts to undefined ecological receptors, such as operating in a sensitive area, accounted for over $6 \%$ of all triggers for marine biodiversity offsets.

\subsection{Definition of offsets}

Limited information relating to the definition of offsets for seven projects reduces the sample size to 35 for this section of the analysis ( $n=35)$. Only $17 \%$ of these projects provided information relating to ecological indicators of success (e.g. area of habitat required to be rehabilitated) and the consideration of the required finances for this success to be realised. No information relating to marine biodiversity offset definition was provided in documentation for projects in Queensland and the Northern Territory. Impacts triggering biodiversity offsetting requirements were quantified in full in only $54 \%$ of projects. Whilst a degree of impact quantification was present in $86 \%$ of projects, the remaining $14 \%$ of projects included offsets against unquantified impacts. Only $49 \%$ of projects used this information to inform assessments of equivalence between impacts (losses) and offsets (gains) and only $14 \%$ of projects could clearly link all marine biodiversity offsetting requirements to quantified impacts. 
Rehabilitation of habitat, including enhancement or creation of habitat was required in $54 \%$ of the projects reviewed with only $43 \%$ of all project consents stipulating rehabilitation of a similar type of habitat in line with the concept of 'like for like'. Over three quarters of the sample (77\%) included management offset requirements, often related to additional commitments to research. Commitments to research as part of the offset, often to inform baseline assessment and improve future impact assessment, were found in $69 \%$ of the sample. There was a strong overlap between management and research commitments, with $60 \%$ of the sample triggering offsets through management that were to be informed by associated research programmes. Marine biodiversity offsets delivered through averted loss or protection effort and educational measures were applied in $23 \%$ and $17 \%$ of projects respectively but these mechanisms were only ever stipulated in combination with other measures, as components of an offset package. Offset packages that involved a range of mechanisms were applied in $49 \%$ of projects. In over half of all projects (51\%) offsets were to be delivered through contributions to in-lieu funds.

\subsection{Compliance monitoring}

Information relating to the timescales over which biodiversity offset outcomes should be delivered was identified in $3 \%$ of projects reviewed where information relating to the offsetting mechanism was available $(n=35)$. In addition, detail outlining how compliance or success might be ensured, such as through adaptive management or financial bonds, was limited to $11 \%$ of the review sample. Discussion of post-consent compliance monitoring was absent from all project documentation reviewed but has been inferred by the identification of detail relating to the timescales of offset delivery. Similarly, there was no information outlining whether the steps of the mitigation hierarchy were followed sequentially and/or the degree to which avoidance and mitigation were explored in any of the projects.

\section{Discussion}

In line with a similar global trend in terrestrial environments (Maron et al., 2015), the use of marine biodiversity offsets as a regulatory tool has increased across the last decade in Australia (Fig. 1). The use of marine biodiversity offsets in Australia appears to be closely correlated with macroeconomic trends, being more frequent between 2009 and 2013 at a time when export commodity prices and their extraction rose to unprecedented levels (Harvey and Clarke, 2012). Given the importance of exports for Australia's economy and the subsequent demand this creates for increased port capacity and other coastal development, the use of marine biodiversity offsets within infrastructure consenting frameworks could be expected to continue (Australian Government, 2015). However, our review of the implementation of marine biodiversity offsets to date suggests that practice may not always support biodiversity protection and it is not clear that they are consistently meeting the standards required by Australia's biodiversity offsetting policy frameworks.

\subsection{Application of the mitigation hierarchy}

Evidence explicitly outlining how the mitigation hierarchy was followed or led to the identification of biodiversity offsetting requirements was not found in any of the projects reviewed. It is likely that a level of process was followed in most cases yet the policy aim of transparency is clearly not being met in relation to how decisions are being reached. Capturing this information is essential to understand offsetting policy success. 
Despite the lack of information, the processes followed can be inferred from other available information, for example concerning the feasibility of biodiversity offsets, and whether or not biodiversity gains equivalent to the relevant losses were sought. We did not find evidence of the assessment of offset feasibility in any of the project documentation reviewed. A common requirement was for biodiversity offsetting strategies or plans to be developed after the point of consent and submitted to be signed off by the respective regulator or minister without further public scrutiny. The absence of detail of feasibility studies attached to even those offsets which relate to direct rehabilitation of habitat suggest that there may be a degree of assumed success attributed to such efforts. Such assumptions are likely overestimating our ability to create marine biodiversity given the challenges presented by ecological restoration particularly in relation to sub-tidal habitat and our current lack of proven expertise in ecological engineering methods (Bayraktarov et al., 2016; Harper and Quigley, 2005; Jacob et al., 2016; Kentula, 2000). Furthermore, this apparent assumed success could indicate an inappropriate application of the mitigation hierarchy with offsets being applied without full exploration of impact avoidance and mitigation opportunities.

\subsection{Quantification of impact and the equivalence of biodiversity offsets}

Quantification of all triggers for biodiversity offsets was recorded in only $54 \%$ of projects and $14 \%$ of projects required offsets against unquantified impacts $(n=42)$. This suggests that for most projects it is the risk of impact that has triggered offsetting requirements rather than a formal quantification of how much residual impact needed to be offset. Without this quantification, it is difficult to plan direct offsetting mechanisms and consider other aspects such as equivalence. It also raises questions as to how an aim of NNL might be achieved or measured in the absence of a robust understanding of what is being lost.

Overall, $43 \%$ of projects identified stipulated direct rehabilitation of a similar type of habitat to that lost, and only $14 \%$ of projects used an assessment of equivalence to inform definition of what and how much rehabilitation was required $(n=35)$. Direct impact to seagrass (seagrass habitat removal) was the most frequent trigger for marine offsets and these impacts were quantified in most projects. Approximately half $(48 \%, n=35)$ of projects presenting impacts to seagrass considered the issue of equivalence and the majority of those led to habitat restoration or 'like for like' biodiversity offsets. Seagrass habitat is afforded protection in all Australian states (Kilminster et al., 2015; Kirkman, 1997), ranging from direct protection of habitat or indirectly through the protection of fish productivity or water quality targets (Kilminster et al., 2015). Well documented and extensive losses of seagrass habitat across much of Australia's coastline have also led to guidelines in a number of states that mandate the mitigation hierarchy when assessing impacts on seagrass (Kilminster et al., 2015). Perhaps uniquely among receptors, seagrass often has relatively well understood baselines, likely a result of the relative ease of data collection, and techniques for seagrass restoration have been subject to considerable scientific attention (Paling et al., 2009). 
In contrast, mobile species such as turtles and marine mammals were the ecological receptors for which offsets were most commonly based on unquantified residual impacts. This is perhaps not surprising given that impacts to such species are more difficult to measure and predict because of the large and variable ranges across their lifecycles (Butler et al., 2010; Crowder and Norse, 2008). Consequently, quantifying impact on these receptors to a degree of certainty needed for decisionmaking within EIA is extremely difficult (Robertson, 2006). Indirect impact pathways, such as the loss of foraging opportunity through disturbance, account for the majority of offset triggers for such species. Quantifying these indirect impacts and pairing them with an offset action to realise an aim of NNL is challenging. This may be why risks posed to these species are frequently unquantified in the documentation reviewed and for potential impacts to result in a broader approach to offsetting, to improve baseline data or to better manage the relevant area as a whole. Indeed, over three quarters $(82 \%, n=35)$ of the offsets identified related to broader 'out of kind' mechanisms where biodiversity gains are less easily calculated including often undefined management, research and education with over half of all projects requiring such measures included in a 'package' of offsets.

\subsection{Compliance monitoring}

We did not identify any discussion of post-consent compliance monitoring of biodiversity offset projects within the project documentation reviewed, and only $11 \%$ of projects $(n=35)$ set out measures to assure success of offset projects, such as adaptive management or financial bonds. This apparent lack of planning to review the success or otherwise of offsets is unsurprising given the low levels of impact quantification and definitions of biodiversity offset success. Clearly, setting measurable compliance targets is challenging without being able to specify what impacts need to be offset. Even where such targets are available, direct offsetting mechanisms such as habitat restoration can be a difficult exercise, and are associated with significant financial commitments over prolonged time periods (Brown and Lant, 1999; Kentula, 2000). Where an option for 'out of kind' offsetting exists as part of policy, this might be an attractive option for project proponents and/or regulators, in particular if it also alleviates the costs of monitoring and adaptive management and the risks of noncompliance.

Broad measures such as offset packages were applied in nearly half of the projects and almost always included 'out of kind' offsetting mechanisms, such as research or education. Over half of projects surveyed involved financial offsets to be paid into in lieu funds. In some circumstances, this might mean an opportunity to pool funds and prioritise conservation effort on larger scales to greater benefit than on a per project basis (Dutson et al., 2015) but again can lead to challenges in reconciling the biodiversity benefits with the specific impacts incurred. Broader measures such as offset packages and the pooling of financial contributions across several projects require careful accounting if they are to contribute to an aim of NNL.

These approaches represent a shift away from ecological measures of success, such as hectares of habitat to be rehabilitated, for the project proponent. Indicators of success for research and education programmes appear to relate to the measurement of investment rather than ecological gains. This passes the responsibility of delivering biodiversity gains to the government or recipient of the investment and away from the project proponent. Understandably, this might be attractive to both project proponents and regulators because it reduces the uncertainty and risk of compliance failure associated with a less flexible definition of the requirements for biodiversity offsets. 


\subsection{How close to NNL is current marine practice?}

Our review suggests that in Australian marine environments, biodiversity offsetting may not be achieving an aim of NNL of biodiversity - or at the very least it is difficult to assess from project documentation whether such aims are being met. Whilst offsetting policies in Australia generally state a preference for direct and 'like for like' offsetting measures, there is explicit flexibility available within them to accept 'out of kind' measures for marine environments (Australian Government, 2012). However, this flexibility does not negate the need for the application of principles relating to the application of the mitigation hierarchy, effective compliance or equivalence (Bos et al., 2014). Strict accounting should be required in the application of 'out of kind' biodiversity offsets, to allow for an appraisal of the performance of offsets in terms of meeting an aim of NNL.

Limited explicit written evidence was identified describing the application of the key principles for biodiversity offsetting success - equivalence, compliance, and the application of the mitigation hierarchy within marine development consent processes. This could suggest that these guiding principles are not being considered within the current implementation of marine biodiversity offsets in Australia. An alternative explanation for the apparent absence of consideration of these key principles could be that they are not easily applied or feasible when faced with the challenges specific to marine environments.

A final issue our review highlights is the absence of a transparent process outlined in biodiversity offsetting policies and guidelines as to how these principles should be explored and through which offsetting requirements can be agreed and evidence presented. Current practice does not capture the true success of biodiversity offsetting policy whereby offset feasibility drives the iterative application of the mitigation hierarchy and the avoidance and mitigation of impacts to levels where offsets are not required (Fig. 1b). The processes followed to determine biodiversity offset requirements are important to understand whether biodiversity offsetting in marine environments is being applied with a view to protecting biodiversity or as a way to manage the challenges of marine EIA. Transparency is one of the key aims of existing biodiversity offsetting policy in Australia (Australian Government, 2012) and is particularly important where 'out of kind' offsetting mechanisms have been applied that may be unlikely to provide direct biodiversity gains. Better documentation on how offsets are being determined could help allay concerns that offsets are serving to shortcut processes within EIA in order to streamline the environmental consenting process (Jacob et al., 2016). 


\section{Conclusion}

Contrary to evidence in Europe (Vaissière et al., 2014), marine biodiversity offsets have been applied often within the consenting of marine developments in Australia, particularly in the states of Queensland and Western Australia. While some offsets have been direct (such as seagrass habitat restoration), far more have been through 'out of kind', indirect mechanisms - often involving packages of education, management and research and/or contributions to larger in lieu funds. The application of biodiversity offsets in a marine context has to account for the large amount of uncertainty in ecological outcomes both through impacts and proposed offsets (Crowder and Norse, 2008). Offsetting policies in Australia do this by explicitly allowing flexibility in the amount of indirect offsetting in marine contexts (Australian Government, 2012). The application of this flexibility requires careful documentation and accounting to avoid misuse, and ensure that biodiversity losses are truly offset. In the public documentation we reviewed we were unable to follow how decisions were made about biodiversity offsetting requirements. It is plausible that many of the issues identified within this review are common to both terrestrial and marine environments, particularly in relation to issues of transparency, the inappropriate application of the mitigation hierarchy, and ineffective compliance monitoring. The limited evidence available could also be interpreted as an indication that the challenges associated with the marine application of offsets are preventing the rigorous application of key offsetting principles. Obstacles to the comprehensive application of biodiversity offsetting principles in Australia include the absence of clearly defined property rights and associated issues of competing policy drivers for management of marine areas; and in some cases, a restricted understanding of impact pathways. These challenges could be leading to a 'short circuiting' of processes to avoid the difficult task of defining 'like for like' biodiversity offsets and a bias towards 'out of kind' mechanisms. It is more difficult to establish equivalence between biodiversity gains and losses with 'out of kind' mechanisms, as such careful accounting is required to achieve an aim of NNL.

With current global trends pointing towards intensifying development of ocean-based economies and a corresponding increase in development pressures on marine biodiversity (OECD, 2016), offsetting could become increasingly integral to effective management of marine environments. Despite the growing popularity of biodiversity offsets globally, very few policies provide specifically for their application in marine contexts (Niner et al., 2017). Australia has one of the most developed policy frameworks for biodiversity offsetting in the world, and has only recently started the process of developing its first marine-specific offsetting policy (Maron et al., 2016). The Australian experience is illustrative of the challenges associated with marine application of biodiversity offsetting, in particular the challenge of reconciling the need for practical flexibility with the fundamental objective of NNL. Addressing these challenges in the context of intensifying ocean-based development is likely to require both focused effort to address outstanding scientific and technical challenges, and the possible re-interpretation of the concept of NNL, for example by allowing 'trading up' of biodiversity losses for gains of greater conservation value (Habib et al., 2013). Whilst this is currently unsupported by Australian offsetting policy, there have been preliminary indications that there may be societal support for such an increase in flexibility (Rogers and Burton, 2017). 


\section{References}

ANEDO, 2014. Assessment of the adequacy of threatened species \& planning laws threatened species \& planning laws.

Australian Government, 2017. Bilateral agreements [WWW Document]. URL http://www.environment.gov.au/protection/environment-assessments/bilateral-agreements (accessed 5.22.17).

Australian Government, 2015. Budget Paper No. 1: Budget Strategy \& Outlook - Statement 2: Economic Outlook [WWW Document]. URL http://budget.gov.au/201516/content/bp1/html/bp1_bs2.htm (accessed 1.12.16).

Australian Government, 2012. Environment Protection and Biodiversity Conservation Act 1999: Environmental Offsets Policy. Departement of Sustainability, Environment, Water, Population and Communities, Canberra.

Bayraktarov, E., Saunders, M.I., Abdullah, S., Mills, M., Beher, J., Possingham, H.P., Mumby, P.J., Lovelock, C.E., 2016. The cost and feasibility of marine coastal restoration. Ecol. Appl. doi:10.1890/15-1077

BBOP, 2012. Standard on Biodiversity Offsets. Washington, DC.

BenDor, T., 2009. A dynamic analysis of the wetland mitigation process and its effects on no net loss policy. Landsc. Urban Plan. 89, 17-27. doi:10.1016/j.landurbplan.2008.09.003

Bos, M., Pressey, R.L., Stoeckl, N., 2014. Effective marine offsets for the Great Barrier Reef World Heritage Area. Environ. Sci. Policy 42, 1-15. doi:10.1016/j.envsci.2014.05.002

Boyes, S.J., Elliott, M., 2014. Marine legislation--the ultimate "horrendogram": international law, European directives \& national implementation. Mar. Pollut. Bull. 86, 39-47. doi:10.1016/j.marpolbul.2014.06.055

Brown, P.H., Lant, C.L., 1999. Research: The Effect of Wetland Mitigation Banking on the Achievement of No-Net-Loss. Environ. Manage. doi:10.1007/s002679900190

Brown, S.C., Veneman, P.L.M., 2001. Effectiveness of compensatory wetland mitigation in Massachusetts, USA. Wetlands. doi:10.1672/0277-5212(2001)021[0508:EOCWMI]2.0.CO;2

Bull, J.W., Hardy, M.J., Moilanen, A., Gordon, A., 2015. Categories of flexibility in biodiversity offsetting, and their implications for conservation. Biol. Conserv. doi:10.1016/j.biocon.2015.08.003

Bull, J.W., Suttle, K.B., Gordon, A., Singh, N.J., Milner-Gulland, E.J., 2013. Biodiversity offsets in theory and practice. Oryx 47, 369-380.

Butler, A.J., Rees, T., Beesley, P., Bax, N.J., 2010. Marine Biodiversity in the Australian Region. PLoS One 5, e11831. doi:10.1371/journal.pone.0011831

Corps, EPA, 1990. Memorandum of agreement between the environmental protection agency and the department of the army concerning the determination of mitigation under the Clean Water Act Section 404(b)(1) guidelines.

Crowder, L., Norse, E., 2008. Essential ecological insights for marine ecosystem-based management and marine spatial planning. Mar. Policy 32, 772-778. doi:10.1016/j.marpol.2008.03.012 
Day, J.C., Dobbs, K., 2013. Effective governance of a large and complex cross-jurisdictional marine protected area: Australia's Great Barrier Reef. Mar. Policy 41, 14-24. doi:10.1016/j.marpol.2012.12.020

Department of the Environment and Energy, 1999. Environment Protection and Biodiversity Conservation Act 1999 (EPBC Act). Australian Government, Canberra.

Dutson, G., Bennun, L., Maron, M., Brodie, J., Bos, M., Waterhouse, J., 2015. Determination of suitable financial contributions as offsets within the Reef Trust. Cambridge.

Fairfull, S., 2013. Fisheries NSW Policy and guidelines for fish habitat conservation and management. Wollongbar. doi:ISBN 9781742562834

Gibbons, P., Lindenmayer, D.B., 2007. Offsets for land clearing: No net loss or the tail wagging the dog? Ecol. Manag. Restor. 8, 26-31. doi:10.1111/j.1442-8903.2007.00328.x

Habib, T., Habib, D., Farr, R., Schneider, S., 2013. Economic and Ecological Outcomes of Flexible Biodiversity Offset Systems. Conserv. Biol. 27, 1313-1323.

Harper, D.J., Quigley, J.T., 2005. No net loss of fish habitat: a review and analysis of habitat compensation in Canada. Environ. Manage. 36, 343-355. doi:10.1007/s00267-004-0114-x

Harvey, N., Clarke, B., 2012. Environmental Impact Assessment in Practice, 1st ed. Oxford University Press, Melbourne.

Jacob, C., Pioch, S., Thorin, S., 2016. The effectiveness of the mitigation hierarchy in environmental impact studies on marine ecosystems: A case study in France. Environ. Impact Assess. Rev. 60, 83-98. doi:10.1016/j.eiar.2016.04.001

Kentula, M.E., 2000. Perspectives on setting success criteria for wetland restoration. Ecol. Eng. 15, 199-209. doi:10.1016/S0925-8574(00)00076-8

Kilminster, K., McMahon, K., Waycott, M., Kendrick, G. a., Scanes, P., McKenzie, L., O’Brien, K.R., Lyons, M., Ferguson, A., Maxwell, P., Glasby, T., Udy, J., 2015. Unravelling complexity in seagrass systems for management: Australia as a microcosm. Sci. Total Environ. doi:10.1016/j.scitotenv.2015.04.061

Kirkman, H., 1997. Seagrasses of Australia. Libro 36.

Madsen, B., Carroll, N., Moore Brands, K.K., Bennett, G., 2010. State of Biodiversity Markets: Offset and Compensation Programs Worldwide I UNDP. Washington, DC.

Maron, M., Gordon, A., Mackey, B.G., Possingham, H.P., Watson, J.E.M., 2015. Conservation: Stop misuse of biodiversity offsets. Nature 523, 401-403. doi:10.1038/523401a

Maron, M., Hobbs, R.J., Moilanen, A., Matthews, J.W., Christie, K., Gardner, T.A., Keith, D.A., Lindenmayer, D.B., McAlpine, C.A., 2012. Faustian bargains? Restoration realities in the context of biodiversity offset policies. Biol. Conserv. 155.

Maron, M., Walsh, M., Shumway, N., Brodie, J., 2016. Reef Trust Offsets Calculator. Brisbane, Queensland, Australia.

McKenney, B.A., Kiesecker, J.M., 2010. Policy development for biodiversity offsets: a review of offset frameworks. Environ. Manage. 45, 165-176.

Miller, K.L., Trezise, J.A., Kraus, S., Dripps, K., Evans, M.C., Gibbons, P., Possingham, H.P., Maron, M., 
2015. The development of the Australian environmental offsets policy: from theory to practice. Environ. Conserv. 42, 306-314.

Moilanen, A., van Teeffelen, A.J.A., Ben-Haim, Y., Ferrier, S., 2009. How Much Compensation is Enough? A Framework for Incorporating Uncertainty and Time Discounting When Calculating Offset Ratios for Impacted Habitat. Restor. Ecol. 17, 470-478. doi:10.1111/j.1526100X.2008.00382.x

Niner, H.J., Milligan, B., Jones, P.J.S., Styan, C.A., 2017. A global snapshot of marine biodiversity offsetting policy. Mar. Policy 81, 368-374. doi:10.1016/j.marpol.2017.04.005

OECD, 2016. The Ocean Economy in 2030. OECD Publishing, Paris. doi:10.1787/9789264251724-en

Paling, E.I., Fonseca, M., van Katwijk, M.M., van Keulen, M., 2009. Seagrass Restoration, in: Coastal Wetlands - An Integrated Ecosystem Approach. pp. 687-713.

Queensland Government, 2016. Queensland Environmental Offsets Policy (version 1.2). Biodiversity Integration and Offsets, Department of Environment and Heritage Protection, Australia.

Robertson, M., Hayden, N., 2008. Evaluation of a market in wetland credits: entrepreneurial wetland banking in Chicago. Conserv. Biol. 22, 636-646. doi:10.1111/j.1523-1739.2008.00963.x

Robertson, M.M., 2006. The nature that capital can see: science, state, and market in the commodification of ecosystem services. Environ. Plan. D Soc. Sp. 24, 367-387. doi:10.1068/d3304

Rogers, A.A., Burton, M.P., 2017. Social preferences for the design of biodiversity offsets for shorebirds in Australia. Conserv. Biol. doi:10.1111/cobi.12874

Soulé, M.E., 1985. What is Conservation Biology ? 35, 727-734.

ten Kate, K., Bishop, J., Bayon, R., 2004. Biodiversity offsets: Views, experience, and the business case. IUCN--The World Conservation Union, Gland, Switzerland and Cambridge, UK.

UNEP, 2012. Global environment outlook 5: Environment for the future we want, Population and Development Review. doi:10.2307/2807995

UNEP-WCMC, 2016. Marine No Net Loss: A feasibility assessment of implementing no net loss of biodiversity in the sea. Cambridge.

Vaissière, A.-C., Levrel, H., Pioch, S., Carlier, A., 2014. Biodiversity offsets for offshore wind farm projects: The current situation in Europe. Mar. Policy 48, 172-183. doi:10.1016/j.marpol.2014.03.023

WAMSI, 2014. Dredging Science Node I WAMSI [WWW Document]. URL http://www.wamsi.org.au/dredging-science-node\#3 